\title{
A review paper on foam-mat drying of fruits and vegetables to develop powders
}

\begin{abstract}
In this paper a review of Foam-mat drying process for fruits and vegetables is discussed to develop quality powders. Foam-mat drying is a new drying technique for foods which are highly heat sensitive and very sticky to dry. Foods contain a lot of compounds which are very sensitive to high temperature for long time. By using this drying technique product is dried in a very short time with minimum quality changes. Fruits and vegetables pastes are mixed with different foaming agents (egg albumin, soy protein, egg white, Lecithin etc.) and foam stabilizers (carboxymethyl cellulose, pectin etc.) in different concentration to introduce stable foams. Foams are dried in trays by application of hot air and milled to develop free flowing powders. Powders developed by this drying technique have maximum preservation of the compounds which are very heat sensitive.
\end{abstract}

Keywords: human beings, categories, food materials, spoilage, raw foods
Volume 6 Issue 6 - 2018

\section{Javed lqbal M,Aleem Abbas, Hamad Rafique, Furqan Nawaz M,Ammad Rasool}

Department of food science and technology, University of Agriculture Faisalabad, Pakistan

\section{Correspondence: Javed lqbal M, Department of food science and technology, University of Agriculture Faisalabad, Basti Balochan, Chak No.55/p, Rahim yar khan, Punjab, Pakistan, Tel +9233I6837033, Email Muhammadjavediqbal45@gmail.com}

Received: October 24, 2018 | Published: December 10, 2018

\section{Introduction}

Food is a basic need for human beings which is required to get energy to do our daily activities. Fruits and vegetable are agriculture crops which are grown in surplus amount during their season. A large proportion of fruits and vegetables get wasted of due to lack of proper processing and storage. There are different type of food materials which are grouped in different categories namely perishable, nonperishable, raw foods, fermented foods. All these foods have their different shelf life. Raw food materials after a period start spoilage, which is caused by different microbial, physical and chemical agents. All the fruits and vegetables are very perishable, containing higher amount of water. Water is a main source for the bacterial growth and proliferation. Water present in food also takes part in different chemical reactions such as oxidation and non-enzymatic browning. Enzymatic and microbial activity also base on water availability. ${ }^{1}$ So we can remove or lower the water contents in our foods to make it unavailable for different kind of organisms which cause food spoilage. Fruits and vegetables have only few days shelf life after harvest. After few days they are subjected to microbial and enzymatic spoilage which result into off flavor and color. Drying is a primary process to preserve different fruits and vegetables. In drying fruits and vegetables are subjected to heat, which lowers the water contents of fruits and vegetables and reduces the growth of different enzyme and microbes and increases the product stability. ${ }^{2}$ Moreover by drying product volume is decreased and it reduces the cost of packaging ,transportation and storage. There are different drying method such as direct sun drying, solar augmented drying, freeze drying, microwave drying, vacuum drying, infrared drying. Selection of a suitable drying method is very important in cost and final quality of the dried product. Some of these drying method need of high installment, energy expenses make them not suitable. Many compounds in the fruits and vegetables are very sensitive to temperature .Foam-mat drying is a new and very suitable drying technique which have high drying rate with minimum quality changes in our final product.

\section{Foam-mat drying}

In the drying of liquids foods containing higher amount of water, foam-mat drying is a new technique in the field of drying technology. It is a best suitable drying technique for those fruits and vegetable extracts which are very sensitive to heat and those which are viscous, sticky and difficult to dry. With this technique a large range of food materials (e.g. Milk, vegetables puree, fruit juices, soluble coffee etc.) are dried without quality changes. ${ }^{3}$

Foam-mat drying is a technique by which aqueous food concentrates are air dried at lower temperature to lower the moisture contents in food and form a stable honey comb like porous sheet which is milled to form powders. In the foam-mat drying technique the surface area of the product which is to be dried increased by foam formation and time required for the drying of foamed product decreased than non-foam dried products (Muthukumaran et al. 2007). The product obtained from foam-mat drying process is better quality ,porous and retain original properties when reconstituted . This drying technique is very cast effective and suitable for heat sensitive food components due to relatively fast drying, high quality and easily reconstitution of product. ${ }^{3}$

Foam-mat drying process developed by Morgan ${ }^{4}$ in the western regional research laboratory of USA in the Agriculture department. In this technique foamed food concentrates are dried by application of hot air at atmospheric pressure. It is reported that foam-mat drying method is coast effective than vacuum, spray drying and freeze drying methods. $^{4}$

\section{Foams}

Generally three methods used for formation of food foams.

a) Sparager: In this method gas is introduced in liquid through porous sparager. All portion of liquid will be converted into foams if large amount of gas is incorporated.

b) Whipping (Beating): In this method liquid is continuously agitated with specially designed devices. In this method of foam formation liquids are subjected to higher mechanical stress, shear and more uniform distribution of air in liquids as compare to sparager method.

c) Shaking: Third and rarely used method of foam formation is shaking. Shaking is very slow process and develop foams of lower volumes than by whipping ${ }^{3}$ 


\section{Foaming agents}

Foaming agents are used to incorporate the air in concentrates which result into decrease in drying rate. There are different kind of proteins which used to induce very fine foams such as egg albumin and soybean protein. Performance of foaming agents can be measured by its foaming properties and final qualities of powders. Foaming properties of different foaming agents can be affected by many factors such as concentration of foaming agents, Solid content of concentrates, Whipping time and room temperature during whipping.

\section{Drying process}

There are following steps of foam-mat drying method which are given below.

a. Fruit and vegetable extracts or any liquid food material for drying.

b. Addition of foaming agents, foam stabilizers and whipping to incorporate air in concentrate to develop stable foams.

c. Spreading of foams in a tray and drying in dryer.

d. Scrapping from trays and disintegration of porous mat to foam free flowing powders.

As the process of foam-mat drying developed by Morgan by which liquid and semisolid foods are dried to desired moisture level. In this process liquid concentrates are mixed with different foaming agents (e.g. egg whites, soy proteins, glycerol Monostearate, carboxymethyl cellulose etc.) (Muthukumaran et al. 2007). Egg white made of high quality proteins and used as a foaming agent), foam stabilizers and mixed or whipped to incorporate air to foam stable foams. These foams are spreaded in the form of sheet in trays and dried by application of hot air relatively at lower temperature in range of 65 to $85^{\circ} \mathrm{C}$ (Figure $1) .^{3}$

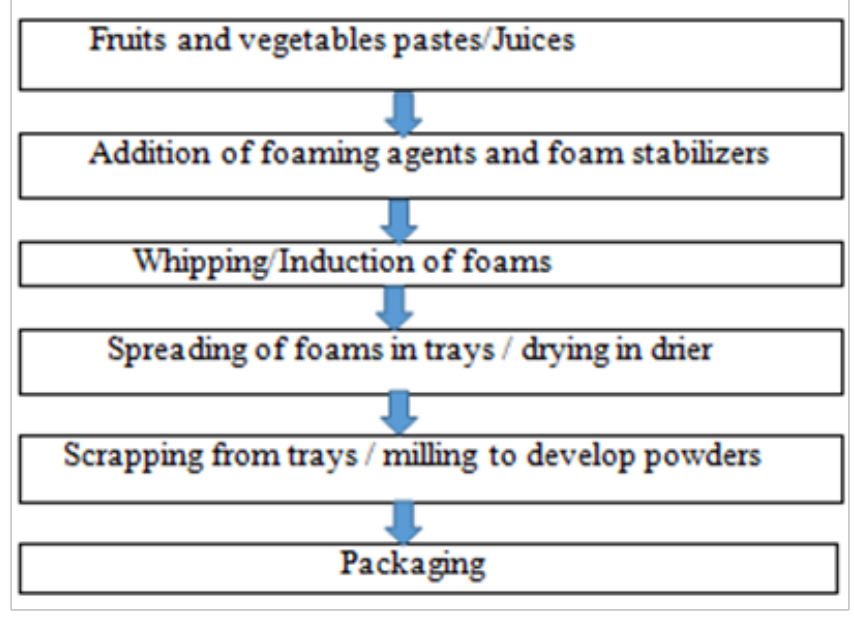

Figure I It shows the flow chart of foam-mat drying process

\section{Review of literature}

Franco et al..$^{5}$ conducted a study to develop yacon juice powder using foam-mat drying technique. Two yacon juice concentration (8Brix and24-Brix) were foamed by egg albumin and dried at different temperature $\left(50^{\circ} \mathrm{C}, 60^{\circ} \mathrm{C}\right.$ and $\left.70^{\circ} \mathrm{C}\right)$ and different sheet thickness $(0.5 \mathrm{~cm}, 1.0 \mathrm{~cm}$ and $1.5 \mathrm{~cm})$ in drying trays. Powders were analyzed for different physicochemical analysis. Density, solubility index and microstructure of powders were not affected by drying conditions while water activity and moisture content reduced. Increase in temperature and reduction in sheet thickness were found best for good quality powder.

Rajkumar et al. ${ }^{6}$ foam-mat drying of mango pulp was conducted by using continuous foam-mat drier. Study was conducted by using different concentration of egg albumin as foaming agent, methyl cellulose as foam stabilizer and different thickness of foam-mat sheet at different temperatures. Using (10\%) egg albumin, $(0.5 \%)$ methyl cellulose and $1 \mathrm{~mm}$ thickness of mat at $60^{\circ} \mathrm{C}$ were found optimum for foam-mat drying of mango pulp. Time required for foam-mat drying was less than non-foam mat dried flakes. Moisture diffusion of nonfoamatted and non-foamatted dried mango pulp was observed 5.3 and $9.7 \times 10^{9} \mathrm{~m} / \mathrm{s}$. Less quality changes were observed in foam-mat dried flakes then non-foam mat dried mango pulp flakes.

Kandasamy et al. $^{7}$ papaya powder was produced by foammat drying method and physicochemical properties of papaya powder studied. Foams produced in papaya pulp by using different concentration of egg albumin $(5,10,15$ and $20 \% \mathrm{w} / \mathrm{w})$ as foaming agent and whipped for different times $(5,10,15$ and 20 mints) to incorporate air to form stable foams. Foam stability, density and expansion were determined. Foam expansion with concentration of egg albumin $15 \%$ and whipping time 15 mints was calculated $125.62 \%$.Concentration of foam was found significantly affecting the foam expansion. Resulting foam mats of different thickness $(2$, $4,6$ and $8 \mathrm{~mm})$ were dried at different temperature $\left(60^{\circ} \mathrm{C}, 65^{\circ} \mathrm{C}\right.$ and $70^{\circ} \mathrm{C}$ ).Effect of temperature and foam thickness on drying rate was studied. In case of low temperature and high foam thickness drying rate was decreased. Biochemical analysis of reconstituted papaya powder and fresh papaya juice performed. These biochemical analysis results showed that at higher temperature $\left(65\right.$ and $\left.70^{\circ} \mathrm{C}\right)$ and higher foam mat thickness $(4,6$, and $8 \mathrm{~mm})$ total sugar contents, ascorbic acids and B-carotene decreased due to increase in drying time and temperature. No considerable changes were found on TSS, PH and acidity by increase of temperature and foam thickness. It was found that egg albumin concentration (15\%), whipping time (15mints), foam thickness $(2 \mathrm{~mm})$ and drying temperature $\left(65^{\circ} \mathrm{C}\right)$ optimum for foam-mat dried papaya powder.

Abbasi et al. ${ }^{8}$ studied to develop sour cherry powders by foammat drying technique. Egg white $(1,2,3 \mathrm{~g} / 100 \mathrm{~g})$ and methyl cellulose $(1,1.5$, and $2 \mathrm{~g} / 100 \mathrm{~g})$ were used as foaming agents and resulting foams were dried at different temperatures $\left(50^{\circ} \mathrm{C}, 65^{\circ} \mathrm{C}\right.$ and $\left.80^{\circ} \mathrm{C}\right)$ to form powders. Different physicochemical properties solubility, foam density, drainage volume, total anthocyanin content (TAC), PH, browning index, acidity and drying time of sour cherry powders were evaluated. All the parameters total anthocyanin content(TAC), foam density, drainage volume, browning index and drying time reduced by increase in concentration of methylcellulose except PH and solubility of samples which increased with increase in concentration of methyl cellulose .By increase in the concentration of egg white it was found that all parameters except $(\mathrm{PH})$ decreased. Effect of drying temperature on physicochemical properties of foam-mat dried sour cherry powder was also studied. From the results it was found that at $65^{\circ} \mathrm{C}$ sour cherry powder have maximum solubility, PH and TAC, while drying time and browning index decreased with increase in temperature.

Kadam et al. ${ }^{9}$ developed the tomato powder by foam-mat drying technique using egg albumin $(0 \%, 5 \%, 10 \%, 15 \%, 20 \%)$ as foaming agent at different drying temperatures $\left(60^{\circ} \mathrm{C}, 65^{\circ} \mathrm{C}, 70^{\circ} \mathrm{C}\right)$ keeping 
the $2.5 \mathrm{~mm}$ sheet thickness. From the results he found that for the development of stable foams $10 \%$ of foaming agent and 5mints whipping time was optimum. By experiments it was observed as we keep increasing the foaming agent concentration drying rate increase.

Sharada et al..$^{10}$ studied the foam-mat drying of tomato, guava and banana by using different concentration of (egg albumin, soy protein isolate) as foaming agent, using tray drier at $55^{\circ} \mathrm{C}$ to $80^{\circ} \mathrm{C}$. Investigated different drying parameters and found that by foaming treatment large amount of air is incorporated to make structure porous which decreased the drying time. Powder developed by this method has good quality and high reconstitution properties.

\section{Conclusion}

Present review is about Foam-mat drying technique for fruits and vegetables to develop good quality powders. Those fruits and vegetables which are very sensitive to high temperature, sticky and difficult to dry can easily dried by using this technique with preservation of its maximum nutritional values. By using this technique products can be dried in a short time with minimum quality changes in final product.

\section{Acknowledgments}

None.

\section{Conflicts of interest}

There is no conflicts of interest on publishing the article.

\section{References}

1) Ong SP, Law CL. Hydrothermal Properties of various Foods, Vegetables and Fruits. In: Jangam SV, Law CL, editors. Drying of Foods, Vegetables and Fruits. Volume 1. 2010. p. 31-58.
2) Chieh C. Water Chemistry and Biochemistry. In: Hui YH, editor. Food Biochemistry and Food Processing. USA: Blackwell Publishing; 2006. $761 \mathrm{p}$.

3) Kadam DM, Patil RT, Kaushik P. Foam Mat Drying of Fruit and Vegetable Products. In: Jangam SV, Law CL, editors. Drying of Foods, Vegetables and Fruits-Volume 1. 2010.

4) Morgan AI, Ginette LF, Randall JM, et al. Technique for improving instants. In: Food Engineering. 1959;31(9):86-87.

5) Franco TS, Perussello CA, Ellendersen LN, et al. Effect of Foam-mat Drying on Physicochemical and Microstructural Properties of Yacon Juice Powder. LWT-Food Science and Technology. 2015;66:503-513.

6) Rajkumar P, Kailappan R, Viswanathan R, et al. Drying Characteristics of Foamed Alphonso Mango Pulp in a Continuous type Foam-mat Dryer. Journal of Food Engineering. 2006;79(4):1452-1459.

7) Kandasamy P, Varadharaju N, Kalemullah S. Foam-mat Drying of Papaya (Carica papaya L.) Using Glycerol Monostearate as Foaming Agent. Food Science and Quality Management. 2012;9.

8) Abbasi E, Azizpour M. Evaluation of Physicochemical Properties of Foam-mat Sour Cherry Powder. LWT-Food Science and Technology. 2015;68:105-110.

9) Kadam DM, Balasubramanian S. Foam Mat Drying of Tomato Juice. Journal of Food Processing and Preservation. 2011;35(4):488-495.

10) Sharada S. Studies on Effect of Various Operating Parameters and Foaming agents-Drying of Fruits and Vegetables. International Journal of Modern Engineering Research. 2013;3:1512-1519. 